\title{
Naturally Occurring Rock Type Influences the Settlement of Fucus spiralis L. zygotes
}

\author{
William G. Ambrose Jr. ${ }^{1, *}$, Paul E. Renaud ${ }^{2,3}$, David C. Adler ${ }^{4}$ and Robert L. Vadas 5 \\ 1 School of the Coastal Environment, Coastal Carolina University, Conway, SC 29528, USA \\ 2 Akvaplan-niva, 9007 Tromsø, Norway; per@akvaplan.niva.no \\ 3 University Centre in Svalbard, 9170 Longyearbyen, Norway \\ 4 East Coast Outfitters, 2017 Lower Prospect Rd., Halifax, NS B3T 1Y8, Canada; dave@hookedinc.ca \\ 5 Department of Biological Science, University of Maine, Orono, ME 04469, USA; vadas@maine.edu \\ * Correspondence: wambrose@coastal.edu
}

Citation: Ambrose, W.G., Jr.; Renaud, P.E.; Adler, D.C.; Vadas, R.L. Naturally Occurring Rock Type Influences the Settlement of Fucus spiralis L. zygotes. J. Mar. Sci. Eng 2021, 9, 927. https://doi.org/ 10.3390/jmse9090927

Academic Editor: Francesca Cima

Received: 18 July 2021

Accepted: 24 August 2021

Published: 26 August 2021

Publisher's Note: MDPI stays neutral with regard to jurisdictional claims in published maps and institutional affiliations.

Copyright: (c) 2021 by the authors. Licensee MDPI, Basel, Switzerland. This article is an open access article distributed under the terms and conditions of the Creative Commons Attribution (CC BY) license (https:// creativecommons.org/licenses/by/ $4.0 /)$.

\begin{abstract}
The settlement of spores and larvae on hard substrates has been shown to be influenced by many factors, but few studies have evaluated how underlying bedrock may influence recruitment. The characteristics of coastal rock types such as color, heat capacity, mineral size, and free energy have all been implicated in settlement success. We examined the influence of naturally occurring rock types on the initial attachment of zygotes of the brown alga Fucus spiralis Linnaeus 1753. We also assessed the dislodgment of zygotes on four bedrock types after initial attachment in laboratory experiments using wave tanks. Settling plates were prepared from limestone, basalt, schist, and granite, found in the region of Orrs Island, Maine, USA. The plate surfaces tested were either naturally rough or smooth-cut surfaces. We measured the density of attached zygotes after $1.5 \mathrm{~h}$ of settlement and subsequently after a wave treatment, in both winter and summer. The pattern of initial attachment was the same on natural and smooth surfaces regardless of season: highest on limestone (range 7.0-13.4 zygotes $\left./ \mathrm{cm}^{2}\right)$, intermediate on schist $\left(1.8-8.5 \mathrm{zygotes} / \mathrm{cm}^{2}\right.$ ) and basalt (3.5-14.0 zygotes $\left./ \mathrm{cm}^{2}\right)$, and lowest on granite $\left(0.8-7.8\right.$ zygotes $\left./ \mathrm{cm}^{2}\right)$. Patterns of survivorship following the wave treatment were similar to those of initial settlement with the mean survivorship varying from $60.1 \%(\mathrm{SE}=3.8)$ (limestone, smooth substrate) to $31.8 \%(\mathrm{SE}=0.59)$ (granite, natural substrate), and with the highest mean survival on limestone, basalt, and schist, and the lowest on granite. Our results suggest that rock type has a significant effect on zygote attachment and persistence. Patterns of attachment were the same on smooth and rough surfaces, indicating that surface roughness is not the predominant factor controlling the difference in successful attachment among rock types. Other properties of bedrock, possibly grain size, surface free energy, or chemical interaction with the adhesives used by the zygotes, directly affect the attachment of these algal propagules. These results suggest that patterns of benthic community structure could be determined in part by the distribution of bedrock types.
\end{abstract}

Keywords: Fucus; rock type; settlement; attachment; mineral composition

\section{Introduction}

Explaining mechanisms for the variation in community structure on multiple spatial scales is one of the fundamental problems in marine ecology. Physical factors such as water flow [1-4], larval supply [5-9], substratum inclination [10-13], wave exposure [1,14-16], disturbance [17], upwelling [18,19], and salinity [20,21] have all been shown to affect the distribution and abundance of organisms on rocky shores, singly or in combination. One variable that has received relatively little attention, however, is the direct effect of bedrock type on the settlement and development of epibenthic organisms [22-25]. Rock types vary in physical and chemical characteristics that might influence the settlement and survival of sessile organisms and thereby influence community structure. For example, the amount of quartz in substrates can influence the settlement of epibenthic and infaunal 
organisms [26,27]. If substrate minerology is important in the recruitment of marine biota, it would offer considerable insight into explaining the patterns in spatial distribution in these communities.

Physical characteristics of substrates such as substrate roughness, microtopography, refs. [28-41] and mineralogy $[23,27]$ are known to affect the settlement and attachment of marine organisms. Bedrock type can certainly influence these characteristics. It is difficult, however, to compare the results of these studies because the scale of substratum heterogeneity in each study varies widely. Further, little distinction is made between surface heterogeneity on a scale smaller than the size of the propagule ('texture'), and that on a scale larger than the size of the propagule ('contour') [2,35]. The size of features relative to the size of the settling propagule is known to be important in determining the success of settlement [42].

The chemical influence of natural substrates on the adhesion of marine propagules has been open to debate [36,43]. There is increasing evidence that the attachment success of macroalgae is directly linked to the chemical characteristics of the adhesives involved and their interaction with the physical-chemical characteristics of the surface to which they bond [43-46]. The presence of biofilms, which develop rapidly on immersed material, however, can make the identification of causal mechanisms challenging.

Studies of the adhesion of zygotes and larvae to artificial and natural surfaces are not only of academic interest. The need to develop nontoxic coatings to prevent the adhesion of marine fouling organisms has revived this area of research (see reviews by [46,47]). This knowledge has implications for developing materials with anti-fouling properties and building artificial reefs and eco-friendly structures. Furthermore, in areas where coastal geologic formations are highly variable, understanding the effect of rock types on the settlement and attachment of sessile organisms may help explain the variability in successful invasion by nonnative species.

Fucoids are common members of intertidal and subtidal hard substrate communities worldwide, ranging from the Arctic to the tropics [48]. Studies have addressed the importance of surface roughness [49,50], water flow and wave action [16,49,51], and substrate type and surface properties $[43,44,52]$ on the settlement and early development of fucalean algae. No studies that we are aware of, however, have addressed differences in settlement among different bedrock types where these algae regularly occur.

We tested the effects of four naturally occurring rock types and their surface contour on the initial attachment of zygotes of the brown alga Fucus spiralis Linnaeus 1753 . To determine the effect of contour (surface heterogeneity on a scale larger than the size of the settling zygote), adhesion was tested on rock plates that were prepared with both natural surfaces and smooth-cut surfaces. We addressed the following questions in a series of laboratory settling experiments: (1) Are there differences in the primary adhesion of Fucus spiralis zygotes on limestone, schist, basalt, and granite substrates? (2) Do differences in the surface contour of these rock types affect the primary adhesion of zygotes? (3) Does exposure to a wave alter the initial settlement patterns? As there were differences in attachment success to different substrata that were independent of surface contour, we explored other physical and chemical characteristics of natural substrata to explain our results.

\section{Materials and Methods}

\subsection{Rock Types}

The four rock types we used were selected based on their varying physical appearance and geological composition, and because of their close juxtaposition in the intertidal zone (Supplemental Figure S1). All rock types occurred within $4 \mathrm{~km}$ of each other in mid-coast Maine, USA. Basalt and schist were collected from the southeast coast of Bailey Island $\left(43^{\circ} 43^{\prime} 30^{\prime \prime} \mathrm{N}, 69^{\circ} 59^{\prime} 40^{\prime \prime} \mathrm{W}\right)$; limestone was collected from the southwest shore of South Harpswell at an outcrop across from Bar Island $\left(43^{\circ} 44^{\prime} 25^{\prime \prime} \mathrm{N}, 70^{\circ} 00^{\prime} 05^{\prime \prime} \mathrm{W}\right)$; and granite was collected from the southernmost tip of Bethel Point $\left(43^{\circ} 47^{\prime} 30^{\prime \prime} \mathrm{N}, 69^{\circ} 54^{\prime} 40^{\prime \prime} \mathrm{W}\right)$. For a detailed lithologic description of these rock units, see [53]. 
Basalt: This was the youngest rock type used in our study (Triassic age, 195-230 myo). Basalt was collected from an intrusive dike located at Bailey Island, which fills a 5-7 m fissure in heavily folded metasedimentary schist. The mineralogy of the basalt is quite uniform (because parent magma was uniform), and the rock is undeformed and unmetamorphosed (because of its young age). The grain size of this rock is very fine, but not as fine as the Spurwink Limestone used in this study. The homogeneity of basalt and its dark color result in rapid desiccation and quick thermal regulation to the environment [7].

Granite: The granite we used has been identified as two-mica granite on the Orrs Island $71 / 2^{\prime}$ United States Geographic Society quadrangle [53]. This is an intrusive rock of middle to late Devonian age (about 345-370 myo). Minerals include garnet, biotite and muscovite mica flakes, potassium feldspar (which gives the rock its yellow appearance), and significant quartz content. The two-mica granite has a large grain size (relative to the other rocks in this study), and a heterogeneous composition.

Schist: The schist used in this study is a metasedimentary rock of the Cape Elizabeth formation, and is estimated to be of Ordovician, Silurian, or Devonian age (345-500 myo) [53]. Such stratified metasedimentary rocks were laid down in a deep basin environment as fine clays. These layers were then compressed and deformed by the formation of the Atlantic Ocean, which resulted in their metamorphism. The clay component of this and the granite has come from the similar chemical weathering of crustal rocks, and thus, the schist and two-mica granite have similar mineralogy. The main chemical difference between the granite and schist is the presence of aluminum (from the fine clays) in schist. Because of the parallel foliation of the dominant mica flakes in this schist, the microheterogeneity $(<500 \mu)$ of the surface can vary significantly as a result of the exposure of different minerals. Large-scale surface topography (on the scale of meters) is also extremely variable in this rock formation because of the intense folding that the unit has undergone.

Limestone: The limestone we used belongs to the Spurwink Formation [53] and has a very similar tectonic history as the schist (Creasy, pers. comm.). This unit crops out as a thin exposure in the high intertidal zone of a sandflat on the west side of South Harpswell. Due to the thin exposure of this limestone unit (15-30 m), it was difficult to locate in the local study area (future workers are directed to limestone outcrops near Rockport Harbor, Maine). The Spurwink Limestone is a laminated rock that has undergone severe deformation. The dark component resembles the schist in composition and derivation, containing biotite, muscovite, quartz, and feldspar. The lighter colored member is very fine-grained gray limestone that contains $90 \%$ calcium carbonate $\left(\mathrm{CaCO}_{3}\right)$ by definition. Both members were equally represented in the experimental plates due to the highly mixed nature of the rock. The most significant difference between this rock type and others used in this study is the extremely small grain size, and the high levels of $\mathrm{CaCO}_{3}$.

\subsection{Fucus Spiralis}

Zygotes of Fucus spiralis, a brown alga common to the high intertidal zone, were selected for study because of their relatively simple fertilization process and well documented attachment strategy. The Fucus zygote is an excellent model system for bioadhesion studies because it is unicellular, develops synchronously, and adheres rapidly to the substrate after fertilization [54]. F. spiralis was specifically chosen because it is monoecious (male and female reproductive structures on the same thallus), has a wide temporal range of reproductive activity, and is well studied [55]. Attachment of the Fucus zygote to the substrate is a multistage process. Shortly after fertilization, the negatively buoyant zygote drops to the substrate surface [3], and then adheres initially via an extracellular mucilaginous material of unknown chemical composition. After approximately 9 to $12 \mathrm{~h}$, primary rhizoid development is initiated, and the zygote becomes permanently attached to the substrate [54]. 


\subsection{Preparation of Settling Plates}

Settlement plates were prepared from samples of basalt, granite, schist, and limestone collected from bedrock using a sledgehammer. No cobbles or boulders were used. Plates with natural settling surfaces were prepared by first cutting a $1 \mathrm{~cm}$ slab from the surface of a bedrock sample using a slab saw. Smooth surfaces were prepared by cutting $1 \mathrm{~cm}$ slabs from the interior of the bedrock samples. The angle of cuts on all samples was dictated by the foliation, cleavage, and mineral veins in the rocks, which affected the structural integrity of the samples. As the blade of the slab saw was lubricated with oil, cut slabs were vigorously washed to eliminate any possible effect on the adhesion of zygotes (cf. [56]). In order to remove microorganisms and eliminate the formation of a biofilm, the slabs were scrubbed in a hot solution of water, dilute hydrochloric acid, and detergent (Ajax), and then rinsed with fresh water. Slabs were then cut into $5 \mathrm{~cm} \times 5 \mathrm{~cm}(+/-1 \mathrm{~mm}$ plates) with a rock saw (blade water-lubricated). All plates were rinsed in running fresh water for $24 \mathrm{~h}$. Slab thicknesses of between 7 and $12 \mathrm{~mm}$ for the natural plates and 8 and $10 \mathrm{~mm}$ for the smooth plates were maintained to ensure minimal differences in surface properties (see [4]). Ten plates of each surface type of each rock type were prepared, resulting in a total of 80 plates ( 40 natural and 40 smooth).

\subsection{Preparation of Zygote Solution}

We conducted two settlement trials, one in February 1995 ('winter') and one in August 1995 ('summer'). We collected receptacles of Fucus spiralis near Gun Point, Maine (69 $56^{\prime} 55^{\prime \prime}$ W $43^{\circ} 45^{\prime} 55^{\prime \prime}$ N) at low tide on 14 February 1995, and 13 August 1995, respectively. We only collected receptacles that were visibly producing gametes, and these were sealed in a plastic bag with absorbent tissue as a desiccant. Receptacles were stored at $5{ }^{\circ} \mathrm{C}$ for ten days after the February 14 collection, and two days after the August 13 collection until gamete release was induced in the laboratory. To obtain gametes, we placed receptacles in a freshwater-ice bath for five minutes. The receptacles were then desiccated in direct sunlight until they had swelled and emitted gametes (ca. $10 \mathrm{~min}$ ), and then soaked in seawater until a sufficient gamete release had been observed (ca. $1 \mathrm{~h}$ in winter and $45 \mathrm{~min}$ in summer). After release, we manually agitated receptacles to shake off any remaining gametes. This solution was then placed in a growth chamber at $20^{\circ} \mathrm{C}$ for $15 \mathrm{~min}$ on a magnetic stirring plate to keep the gametes in suspension and promote fertilization.

\subsection{Settlement of Zygotes on Plates}

Settlement plates were randomly arranged in two shallow metal trays (natural vs. smooth surfaces) in a $4 \times 4$ grid consisting of 40 plates (10 of each rock type). Natural and smooth plates were placed in different trays to minimize the variation in profile heights of the plates and thereby reduce the possibility that uneven plate heights would modify the water flow and influence settlement. There were no gaps left between plates, and the trays were larger than the $4 \times 10$ plate grid, leaving a $5 \mathrm{~cm}$ perimeter around settling plates. Fifteen minutes prior to zygote addition, artificial seawater (Instant Ocean, $32 \mathrm{psu}$, $5{ }^{\circ} \mathrm{C}$ ) was added to the trays so that all plates were covered by ca. $2 \mathrm{~cm}$ of water. After fertilization ( $15 \mathrm{~min}$ ), we poured $250 \mathrm{~mL}$ of the zygote solution (in suspension) over the settlement plates in a constant flow in a grid pattern to homogenize zygote densities over each plate. The settlement trays were left undisturbed under diffuse fluorescent light at room temperature $\left(14-16^{\circ} \mathrm{C}\right)$ for $1.5 \mathrm{~h}$. The surface water was then carefully siphoned out of the trays with a plastic tube $(6 \mathrm{~mm}$ inside diameter) placed at least $5 \mathrm{~cm}$ from any plate. The flow caused by siphoning, estimated by recording the time required for zygotes on the bottom surface of the tray to pass by 2 plates $(10 \mathrm{~cm})$, was approximately $1 \mathrm{~cm} / \mathrm{s}$.

Five plates of each rock type were chosen at random, using a table of random numbers, from the settlement-plate array for the wave treatment, and the remaining 'control' plates were sprayed with a fine mist of Instant Ocean $\left(32 \mathrm{psu}, 5^{\circ} \mathrm{C}\right)$. These control plates were transferred to individual plastic containers with airtight lids and moist towels underneath and maintained in a horizontal position at $5{ }^{\circ} \mathrm{C}$ until zygotes were counted under a 
dissecting scope. From the remaining plates, one plate of each rock type to be tested for wave-treatment effects was placed in random order in the track of a wave tank (see [16,57] for description). The direction of water flow was recorded for each plate and the surface types (natural vs. smooth) were tested separately. A single $3 \mathrm{~L}$ wave was then released and allowed to wash over the plates and drain through holes behind the plates. We allowed the water to drain off the plates (ca. $30 \mathrm{~s}$ ), and then the plates were carefully transferred to plastic containers with air-tight lids and handled as the control plates described above. The wave treatment experiment was repeated 4 times with rock plates randomly assigned to positions in the flume each time, leading to 5 individuals of each rock type exposed to a wave ('survival' after a single wave treatment), and 5 replicate plates of each rock type serving as controls (initial settlement only).

\subsection{Counting Methodology}

We counted zygotes using a dissecting microscope at $40 \times$ magnification. The $25 \mathrm{~cm}^{2}$ surface of the plates was divided into nine evenly spaced $1 \mathrm{~cm}^{2}$ quadrats. The peripheral $1 \mathrm{~cm}$ of the plates was avoided (to reduce edge effects). A humidity chamber to prevent desiccation was created by placing a moist towel beneath the plate and covering the plate with a gridded petri dish during counting. In order to reduce processing time, we randomly selected six of the nine $1 \mathrm{~cm}^{2}$ areas. We counted the zygotes in each quadrat and calculated a mean number of zygotes per $\mathrm{cm}^{2}$.

\subsection{Statistical Analyses}

Mean zygote densities per square centimeter from the initial attachment trial were compared using a three-way ANOVA with season, rock type, and wave exposure as main factors. Variances were not homogenous until the data were $\log _{10}$-transformed (F-max test, [58]). Separate 3-way ANOVAs were conducted for natural and smooth plates because surface types were tested independently. We used Tukey's HSD post hoc test to compare differences among rock types because there were no significant interactions in either of the ANOVAs.

Zygote densities at initial attachment were significantly different among rock types (Figure 1). It was not possible, therefore, to simply compare zygote densities after the wave treatment plates to reveal how successfully zygotes remained attached to different rock types. In order to examine the success of the initial attachment of zygotes to plates of both natural and smooth surfaces of different rock types following the wave treatment, we calculated zygote 'survivorship' [16]. This was calculated by dividing the mean zygote density found on each surface type and rock type following the wave treatment by the mean zygote density for each plate in each control. The resultant dataset consisted of 8 groups (4 rock types $x 2$ wave treatments) of 5 (number of replicates) percentages for each experiment (summer and winter). These percentages were then arcsine-transformed to make the variances homogenous [59]. The transformed data were analyzed using a twoway ANOVA with season and rock type as main factors. As with the analysis of patterns of initial attachment, we analyzed survivorship data for surface type (natural, smooth) using separate ANOVAs. The interaction term in these ANOVAs was not significant, so as with the 3-way ANOVAs, we used Tukey's HSD post hoc test to compare differences among rock types. We used the terms 'survival' and 'survivorship' to represent the percentage of attached zygotes persisting after the wave treatment, not in the biological sense of surviving for days beyond the treatment. 


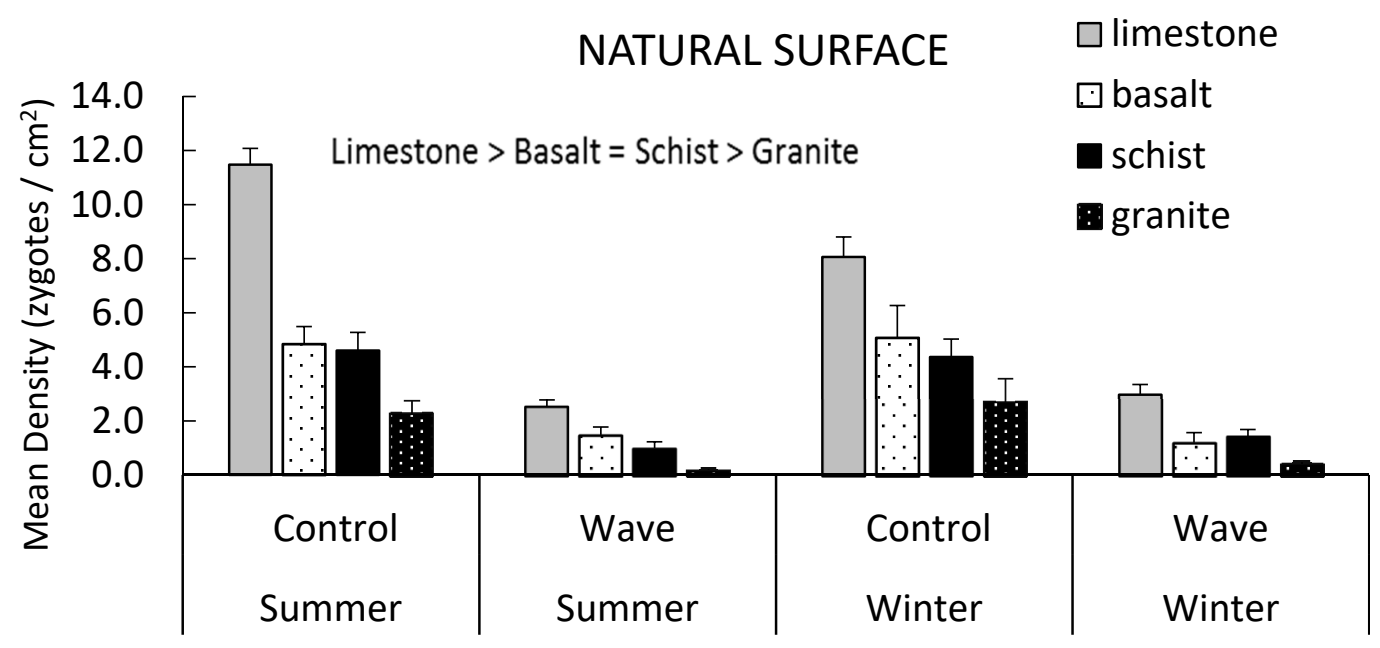

(a)

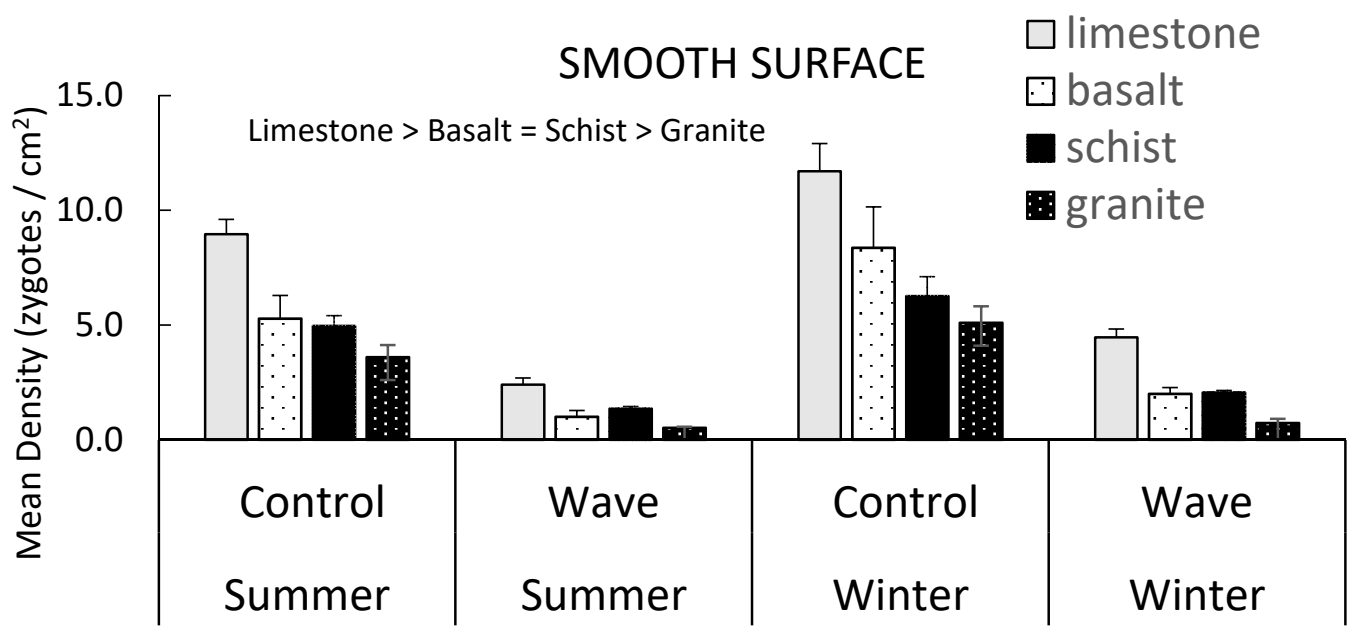

(b)

Figure 1. Mean density (zygotes per $\mathrm{cm}^{2}+1 \mathrm{SE}, \mathrm{N}=5$ ) of Fucus spiralis zygotes on 4 rock types after $1.5 \mathrm{~h}$ of settlement (control) and $1.5 \mathrm{~h}$ of settlement followed by one wave in summer and winter experiments. A three-way ANOVA compared zygote density as a function of season, rock type, and wave treatment (wave or no wave) for each surface type: (a) natural and (b) smooth. The zygote density was higher in winter than summer on smooth plates $(p<0.001)$, but there was no significant difference $(p>0.05)$ between seasons on natural plates. The density was always significantly lower $(p<0.0001)$ regardless of rock type on plates subjected to a wave compared to control plates. The mean density among rock types was compared using Tukey's HSD post hoc test. For both natural and smooth plates, the density was significantly higher $(p<0.0001)$ on limestone than on basalt and schist, which were not significantly different from each other $(p>0.05)$; granite had a significantly $(p<0.0001)$ lower density than all other rock types.

\section{Results}

\subsection{Initial Attachment}

The mean number of zygotes per square centimeter that settled on plates in the winter ranged from 0.67 (natural granite receiving a wave treatment) to 14.2 (smooth limestone control) and in summer from 0.4 (natural granite receiving a wave treatment) to 13.4 (smooth and natural limestone control). There was a significant difference in mean zygote density among rock types and between wave treatments for both natural and smooth surfaces, but there was only a significant difference between seasons on the smooth surface substrate (Table 1). None of the interactions between factors were significant for either surface. Plates subjected to a wave always had lower zygote densities, between $61 \%$ (limestone, smooth, winter) and 91\% (granite, natural, summer), than the control plates. On 
the smooth surface, the mean initial attachment was significantly greater $(p<0.0001)$ in the winter ( 5.1 zygotes per $\left.\mathrm{cm}^{2}, \mathrm{SE}=1.3\right)$ than in the summer experiment $\left(3.5\right.$ zygotes per $\mathrm{cm}^{2}$, $\mathrm{SE}=1.0)$ (Figure 1). For both natural and smooth plates, the density was significantly higher $(p<0.0001)$ on limestone than on basalt and schist, which were not significantly different from each other $(p>0.05)$; granite had a significantly $(p<0.0001)$ lower density than all other rock types. The pattern was the same before and after the wave treatment.

Table 1. Results of 3-way ANOVA analyzing the effect of season (summer and winter), rock type (limestone, schist, basalt, and granite), and wave or no wave on the density of zygotes recorded on settlement plates of natural and smooth surfaces. There were 5 replicate plates of each rock type and flow combination. Data were $\log _{10}$-transformed before analysis.

\begin{tabular}{|c|c|c|c|c|c|}
\hline Natural Surface & & & & & \\
\hline Source & $d f$ & SS & MS & $F$ & $p$ \\
\hline Season & 1 & 0.0001 & 0.0001 & 0.01 & 0.92 \\
\hline Rock type & 3 & 2.3207 & 0.7735 & 53.9 & 0.0001 \\
\hline Wave & 1 & 3.4149 & 3.4149 & 237.9 & 0.0001 \\
\hline Interaction (season $\mathrm{x}$ rock) & 3 & 0.0374 & 0.0125 & 0.86 & 0.46 \\
\hline Interaction (season $x$ wave) & 1 & 0.0261 & 0.0261 & 1.82 & 0.18 \\
\hline Interaction (rock x wave) & 3 & 0.0131 & 0.0044 & 0.30 & 0.82 \\
\hline \multicolumn{6}{|l|}{ Interaction (season $x$ rock) } \\
\hline$x$ wave & 3 & 0.0433 & 0.0144 & 1.01 & 0.39 \\
\hline Error & 64 & 0.9185 & 0.0144 & & \\
\hline Total & 79 & 6.7742 & 0.0858 & & \\
\hline \multicolumn{6}{|l|}{ Smooth Surface } \\
\hline Source & $d f$ & SS & MS & $F$ & $p$ \\
\hline Season & 1 & 0.328 & 0.328 & 23.29 & 0.0001 \\
\hline Rock type & 3 & 1.433 & 0.478 & 33.91 & 0.0001 \\
\hline Wave & 1 & 4.065 & 4.065 & 288.68 & 0.0001 \\
\hline Interaction (season $\mathrm{x}$ rock) & 3 & 0.025 & 0.008 & 0.6 & 0.62 \\
\hline Interaction (season $\mathrm{x}$ wave) & 1 & 0.0004 & 0.0005 & 0.03 & 0.85 \\
\hline Interaction (rock $x$ wave) & 3 & 0.044 & 0.014 & 1.05 & 0.37 \\
\hline \multicolumn{6}{|l|}{ Interaction (season $\mathrm{x}$ rock) } \\
\hline x wave & 3 & 0.016 & 0.005 & 0.38 & 0.77 \\
\hline Error & 64 & 0.901 & 0.014 & & \\
\hline Total & 79 & 6.812 & 0.086 & & \\
\hline
\end{tabular}

\subsection{Survivorship}

Across all treatments, survivorship averaged 27.3\% (SE = 3.2) in the winter and $21.4 \%$ $(\mathrm{SE}=2.5)$ in the summer. The results of the two-way ANOVAs comparing the effects of season and rock type on the survivorship of zygotes after a wave treatment were the same for natural and smooth surfaces (Table 2). The mean survivorship of zygotes was significantly affected by rock type, but not season, and there were no significant interactions in the ANOVAs. On natural rock, there was no significant difference $(p>0.05)$ in mean percent survival of zygotes among limestone, basalt, and schist treatments, but survival was significantly $(p<0.01)$ higher on these rock types than on granite (Figure 2$)$. The survival of zygotes was similar on smooth and natural rock surfaces except that there was no significant difference $(p>0.05)$ in mean percent survival between basalt and granite. 
(a)

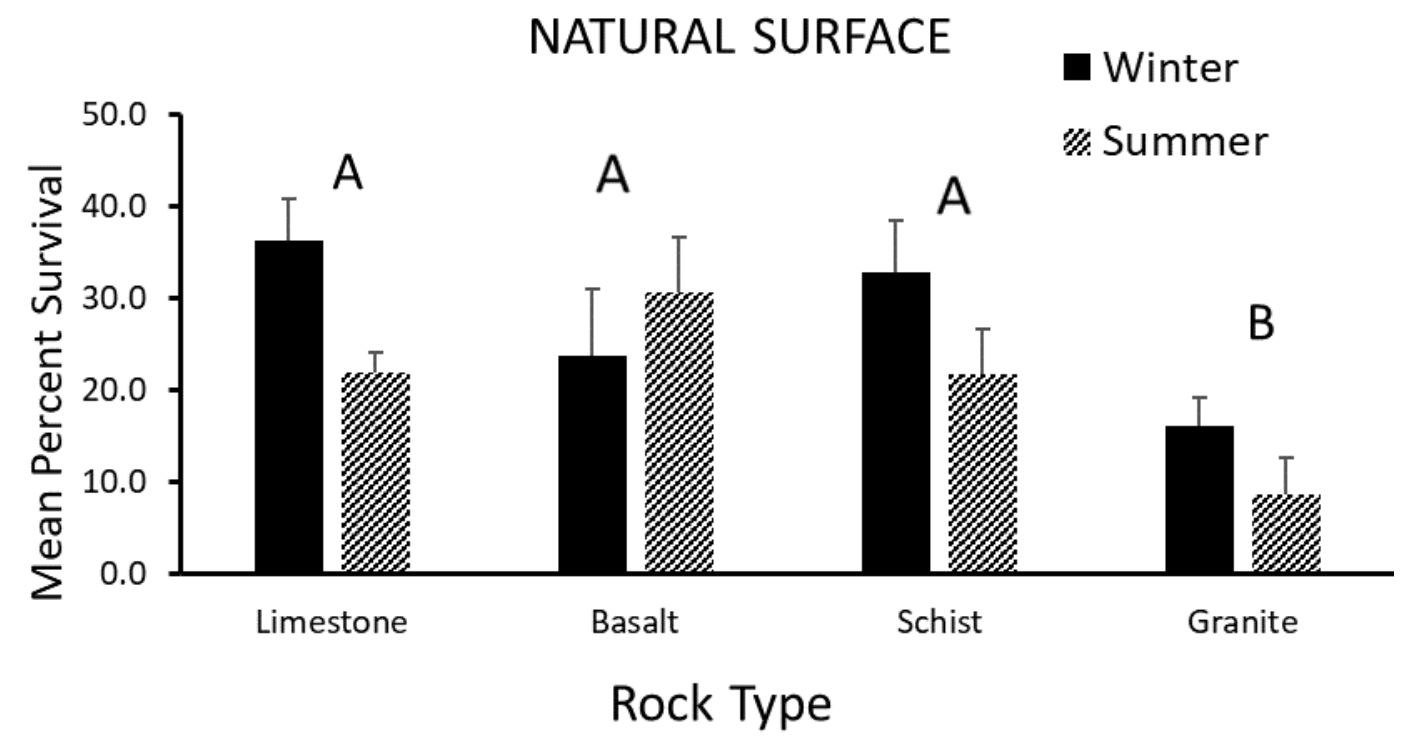

(b)

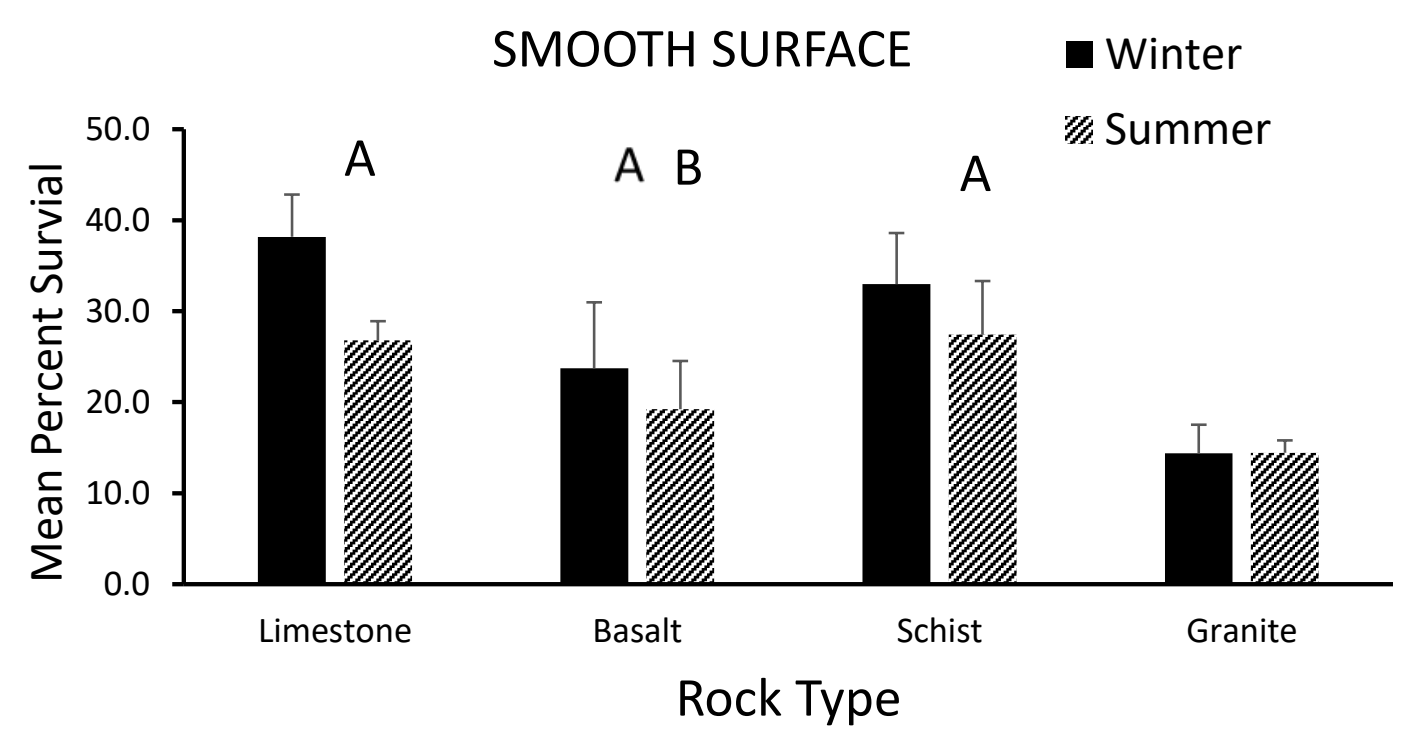

Figure 2. Mean percent survival ( $+1 \mathrm{SE}, \mathrm{N}=5)$ of Fucus spiralis zygotes after one-wave treatment in experiments with natural (a) and smooth (b) rock surfaces. Percentages are based on mean densities of no-wave treatment for each rock type. Arcsine-transformed proportions were compared between seasons and among rock types for each experiment using a two-way ANOVA. The season $x$ rock type interaction was not significant in either ANOVA $(p>0.05)$. Means (by rock type) with a common letter over the bar are not significantly different from each other (Tukey's HSD post hoc test, $p<0.05$ ). 
Table 2. Results of 2-way ANOVA analyzing the effect of season (summer and winter) and rock type (limestone, schist, basalt, and granite) on the mean percent survivorship of zygotes after treatment by a wave. Survivorship is calculated as a percentage based on the mean zygote density of control plates in each rock and surface type. Data were arcsine-transformed before analysis. There were 5 replicates of each rock and surface type combination.

\begin{tabular}{cccccc}
\hline Natural Surface & & & & & \\
\hline Source & $d f$ & $S S$ & $M S$ & $\boldsymbol{F}$ & $\boldsymbol{p}$ \\
\hline Season & 1 & 0.0908 & 0.0908 & 4.11 & 0.051 \\
Rock type & 3 & 0.3953 & 0.1318 & 5.96 & 0.002 \\
Interaction (season x type) & 3 & 0.1133 & 0.0377 & 1.71 & 0.181 \\
Error & 32 & 0.7076 & 0.0221 & & \\
Total & 39 & 1.3071 & & & \\
Smooth Surface & & & & & \\
\hline Source & $d f$ & $S S$ & MS & & \\
\hline Season & 1 & 0.0218 & 0.218 & 1.66 & 0.207 \\
Rock type & 3 & 0.2698 & 0.089 & 6.83 & 0.001 \\
Error & 3 & 0.0258 & 0.0086 & 0.65 & 0.587 \\
Total & 32 & 0.4216 & 0.0132 & & \\
\hline
\end{tabular}

\section{Discussion}

Zygote attachment and survivorship following a wave were greatest on limestone, least on granite, and intermediate on schist and basalt. A wave dislodged some initial settlers, but it did not change the general patterns of initial attachment we recorded. While we did not statistically compare natural and smooth surfaces (experimental design prohibits this), initial attachment patterns were the same between the two surfaces, and patterns of survival were very similar. These results suggest that minerology, fine-scale characteristics of the rock types, or some other characteristic of rock type, and not contour (natural vs. smooth), accounted for the differences we observed.

We examined the initial attachment phase, which may not indicate the effect of bedrock type on zygotes attached for longer periods [16]. The exact timing of the transition from initial mucilaginous adhesion to permanent rhizoidal adhesion is not clear. Initial attachment may occur about one hour after fertilization [43], while another study [54] reported that initial attachment occurs from 3 to $6 \mathrm{~h}$ after fertilization and refers to the time after fertilization as the 'pre-adhesive' stage. The zygote undergoes an adhesive maturation phase from 7 to $9 \mathrm{~h}$ after fertilization [54], which involves the hardening or gelling of the polysaccharide $[3,44]$. The chemical composition of the adhesives involved in the attachment of Fucus zygotes is largely unknown $[54,60]$. There is evidence, however, that polysaccharideprotein complexes are involved [44], and that two polysaccharides, an alginic acid complex and sulfated fucan, and polyphenols make up the adhesive secretion [54,61]. In our study, we had an initial attachment of up to 120,000 per $\mathrm{m}^{2}$, and approximately $25 \%$ were able to maintain adherence after wave exposure. This indicates that even if 3-6 h may be termed a 'pre-adhesion' stage, the shorter time used in our experiment is certainly enough for good settlement and persistence following a wave.

\subsection{Surface Roughness}

The initial attachment of the nonmotile zygote is, in part, dependent on the physical characteristics of the substrate. The most implicated substrate characteristic in earlier studies of settlement and attachment of marine organisms is surface roughness, or contour [34-37,62]. Surface roughness has been quantified with the development of the engineering roughness index, a dimensionless parameter that relates the proportion of the surface that is recessed and the amount of freedom a spore has to move based on surface topography [42,63]. Zygotes are likely to find refuge from turbulent flow in rock substrates 
that are rough enough to offer cracks and crevices that protect germlings [35,44]. Such crevices may be present within a rock type, or between juxtaposed rock types. Most studies on the effects of surface roughness on settling behavior have used artificial substrates (but see $[42,64]$ ). Typically, roughness is examined by cutting or drilling grooves or pits of varying size in otherwise homogenous substrates $[16,34,62,64,65]$, by attaching silica grains of different sizes to a homogenous surface [31,49], or by producing a range of rough surfaces using varying grades of abrasive materials on otherwise smooth materials [66]. These results are helpful in indicating what is possible and, therefore, what can and cannot be expected of larvae (as in these studies), or algal propagules [67]. Although Caffey [68] argues that artificial substrates provide little insight as to the factors influencing attachment in the natural environment, they can, if consistent with field observations, provide valuable corroborative data on control mechanisms.

We did not statistically compare natural and smooth surfaces for the initial attachment or survivorship, because plates of different surface types were held in separate trays (i.e., there was a lack of interspersion of treatments). Settling trays were identical and settlement occurred simultaneously under identical conditions, so it is unreasonable to expect a significant tray effect. Furthermore, analyzing survivorship instead of settler density removes much of the possible variability in the concentrations of the zygote solutions added to each tray. Nevertheless, comparisons between surface types are qualitative.

There were few differences in our study in patterns of initial attachment or survivorship following a wave between plates with natural and smooth surfaces (Figures 1 and 2). With both surface types, limestone, which has the finest grain size and least inherent surface roughness, proved to be most suitable, and granite, which has the largest grain size of the rock types tested, the least suitable for zygote attachment. As this pattern persisted for both natural and smooth surfaces, a factor other than the contour of the surface must explain the variation among rock types.

Although topography on the scale of centimeters to tens of meters is important in assessing intertidal environments and community structure, the effect of substratum microheterogeneity, or texture must also be addressed to investigate settlement processes. For a range of taxa, a microtopography smaller than the length of an organism's attachment point generally reduces settlement [42]. Algal spores and zygotes are typically about $5 \mu \mathrm{m}$ in size, so the most appropriate scale to measure the surface texture of substrates in algal settling experiments may be the grain size of minerals [64]. Mineral grains are the units that are cleaved from rocks as a result of physical weathering. This suggests that grain size can dictate the surface texture in natural environments because the weathering of rocks with large grains will expose larger mineral surfaces than those with small grain size, although it may be difficult to be so conclusive about this parameter for rock types with heterogeneous mineralogic composition (e.g., two-mica granite). Surface heterogeneity on this scale has been shown to affect community structure in many species $[3,35,43,44]$. Although on a large scale, the natural surface of the rocks used in this study can be classified in order of increasing roughness (limestone-basalt-schist-granite), this may not be the appropriate scale for our study. Surface roughness as it applies to zygotes has been defined as the number of surface planes of the substrate encountered by the zygote [44,62]. Zygotes may experience more surface planes on a rock with small grain size, and fewer on a rock with large grain size. Thus, the scale of roughness as it applies to zygotes may be the converse from that determined on a large scale. Future studies should investigate differences in roughness among natural substrata on scales relevant to zygotes.

The limestone used in this study was very fine grained [53], with grains smaller than the typical size of the zygotes used. Such substrata would present a greater number of surface planes for mucilaginous adhesion than would a substrate with large grain size (i.e., granite). This classification would also be relevant for surfaces cut with a diamond blade. The large mineral grains of granite (due to slow cooling of parent magma) and schist (due to recrystallization of marine sediments) were large enough so that individual mineral grains were actually cut, leaving a smooth surface, while the small grains of 
basalt and limestone remained intact. Thus, any advantage in attachment strength due to grain size would persist even if the natural rock surface were cut, which is what we observed in documenting a few differences in the pattern of survival between natural and smooth surfaces (Figure 2). This hypothesis is consistent with the results of one study [64] in which the settlement of barnacle cyprids was enhanced on fine-grained natural rock plates and inhibited on course plates, even though all settlement plates were machine-cut and polished. Our result, however, does not agree with more recent work that suggests that features the same size or smaller than the settling organisms inhibit settlement [69]. Scardino et al. [69], however, found that for very small motile propagules on the order of 7 $\mu \mathrm{m}$, the effect of attachment points was weak, so the relationship between surface features and sizes of settling propagules may not apply to Fucus spores.

It is important to note that while we found no differences between smooth and rough plates in the pattern of initial attachment of zygotes, our results may not be easily extrapolated to the field. In the field, roughness exists on many scales that we did not test in our study. These roughness differences are due in part to rock minerology, wave energy, crystal size, geological processes juxtaposing rock types, and erosional history, and can well influence very local flow patterns and potential attachment angles-and thus, settlement/recruitment. This should be considered in field experiments that may follow from our study.

\subsection{Chemical Interactions between Adhesives and Substrata}

As discussed above, there is evidence that a polysaccharide chain of alginic acid comprises one of the initial attachment adhesives in the Phaeophyta. Alginic acid is a linear 1,4-linked block copolymer comprised of beta-D-mannuronic acid (M) and alpha-Lguluronic acid $(\mathrm{G})$ residues [3]. The strength of polysaccharide gels such as alginate are increased by the binding of $\mathrm{Ca}^{2+}$ [3]. Due to differences in structure, polyguluronic acid has a greater affinity for $\mathrm{Ca}^{2+}$ than for polymannuronic acid. The structure of polyguluronic acid better accommodates insertion of the calcium ion, resulting in cross-linking of the polymer chain and a stiffer gel. Higher concentrations of $\mathrm{Ca}^{2+}$ ions at the surface interface of specific bedrock types may result in more cross-linking of the alginic acid polymer chain, thereby producing a more rigid gel and a stickier adhesive. It is probable that such a difference in $\mathrm{Ca}^{2+}$ concentration exists between limestone and granite because the limestone consists of at least $90 \% \mathrm{CaCO}_{3}$, which readily dissociates. The availability of free calcium ions may partially explain a higher initial attachment and survivorship of zygotes on limestone compared to some other rock types.

\subsection{Free Energy of Rock Surfaces}

Applied research into fouling by marine organisms has focused on the alteration of potential settling surfaces to prevent adhesion. The most implicated physical-chemical characteristic of substrates is the surface free energy, also referred to as wettability [44]. This is defined as an unsatisfied bonding potential at the surface of a material that results in the greater propensity of that surface to bond to dissimilar particles in the surrounding water [45]. Increased surface free energies have been shown to increase the adhesive strength of algal spores [41,44], change the shape of rhizoids that are produced [43], and enhance the attachment of barnacle and bryozoan larvae [70]. The early settlement of meiospores is best described by water contact angle [41], which is related to surface free energy [41]. As this research is generally applied to the development of nontoxic coatings for use in marine industries, artificial substrates such as synthetic polymers, glass, ceramic tiles, and Teflon have been studied in adhesive comparisons $[41,43,44]$. The homogenous composition of these surfaces and their predictable matrices make it possible to measure the free energy of these surfaces and then to compare these measurements with strength of attachment.

The modeling of natural substrates such as rock, however, is much more complex than for artificial surfaces due to the heterogenous nature of natural surfaces. The heterogenous 
mineralogy of natural rock makes surface free energy difficult to measure (Berry, pers. com.). Even the lattice of a simple salt such as $\mathrm{NaCl}$ is heterogenous ( $\mathrm{Na}$ is not the same as $\mathrm{Cl}$ ), so in introducing the highly variable chemical composition of rocks, it is probable that the surface energy of the substrate will vary over small scales within one sample of any given rock type [71]. Furthermore, there will likely be differences in the free energy of surfaces based on the cleavage of the crystals. Adamson [72] indicated that a clean cleavage of a crystal (i.e., through natural weathering) will have a different and probably lower surface energy than would a ground or abraded surface of the same material.

Differences in surface free energy among substrates are also expected to decrease with prolonged immersion in sea water [70,73]. The adsorption of organic and possibly inorganic molecules can occur on clean surfaces, creating a 'conditioning' film within minutes of immersion in sea water $[45,74]$. This film can alter physio-chemical properties such as the surface energy of the original surface and the effect of the settlement of algae (see [75] for review). This effect is important to note when comparing short-term laboratory settling experiments using fresh substrata to possible long-term effects of substrates on community composition in the field. Holm et al. [73] concluded that while surface energy may be important in determining initial settlement patterns in some fouling communities, it is probably not a major influence on long-term community development. Conversely, Callow and Fletcher [45] reported that, although surfaces with different original surface energies acquired similar films, differences in attachment persisted after immersion.

No direct measurements of surface free energy were available for comparison in our study. Nonetheless, it is possible that differences in surface charges contributed to the differences in survivorship among our substrates, and this possibility should be explored in future experiments. The extreme contrast between the chemical composition of limestone and granite, for example, make it probable that differences in surface energies of these substrates exist, and that limestone is the more highly charged of the two (Berry, pers. com.). The surface free energy of limestone aggregate is greater than that for granite aggregate [76], which is consistent with this speculation. While the chemical characteristics of aggregates and natural rocks in the field are not expected to be the same, the relative differences might be. The higher settlement on limestone compared to granite we measured would agree with Callow and Fletcher [45] who found that adhesion for a wide range of organisms is higher on surfaces with higher surface energies.

\subsection{Other Factors}

Other factors that have been suggested to influence algal and larval attachment are salinity gradients [77], color differences [7], $\mathrm{pH}$ gradients [3], substrate hardness [43], and the presence of microbial films [78,79]. The effects of color on attachment have been attributed to differences in thermal properties of dark vs. light substrates [7]. As our experiments were run indoors under diffuse light, color is unlikely to be important (but may certainly be an important contrast between our experiments and settlement under field conditions). A pilot study indicated that there was no detectable difference (to + / - 0.01) in $\mathrm{pH}$ at the substrate-water interface after $1.5 \mathrm{~h}$ among the four rock types. Such an effect cannot be completely discounted, however, because zygotes may be able to detect much smaller differences in $\mathrm{pH}$ than the instrument used could measure [80]. Substrate hardness has been implicated in affecting the adult communities found on rocks because softer rocks (such as limestone) will erode more rapidly than granite or basalt. Hardy and Moss [43] concluded that ephemeral species tend to grow on soft substrates, while perennials occur on hard substrates. Variations in microbial films affect the surface tension of substrates and, hence, attachment $[70,81,82]$. Microbial films were not likely a factor in our experiments, because settling plates were rigorously cleaned and sterilized before testing, experimental trials were short, and the artificial seawater used contained far fewer micro-organisms than did natural seawater. Finally, Amsler et al. [80] reported that surfaces concentrate several nutrients, which stimulate kelp spore chemotaxis or settlement. It is plausible that a 
similar effect may occur in Fucus, but the measurement of this effect was beyond the scope of our study.

\section{Conclusions}

Our results indicate that the adhesion of F. spiralis zygotes is influenced by characteristics of natural rocks other than surface contour and that the general pattern of initial attachment to different rock types we observed persists after the zygotes are exposed to a wave. The microheterogeneity (texture) of substrates based on grain size, the effect of variations in surface charge of natural substrates, and the chemical interaction of the initial adhesives at the substrate interface are suggested as possible factors affecting initial attachment success, consistent with our results of contrasting attachment and survivorship of the zygote on different rock types. The difficulty in assessing characteristics such as free energy in natural substrates and the lack of data on the precise chemical composition of the adhesives produced by settling propagules leave some of these questions open for further study. It is clear, however, that natural substrates present a higher degree of variation in factors affecting settlement than simply different degrees of roughness and that these factors operate within the first few hours of zygote attachment. A further study of this interaction and patterns of settlement among naturally occurring rock types may contribute to a better understanding of attachment of algal spores and to the distribution and dynamics of natural communities on rocky shores. Finally, 26 years have elapsed since our study and, while we do not opine that zygote affinity for different rock surfaces changed as a result of a circa $0.5-1{ }^{\circ} \mathrm{C}$ increase in water temperature [83], many factors that affect settlement could have changed over this period, warranting repeating these experiments.

Supplementary Materials: The following are available online at https:/ / www.mdpi.com/article/10 $.3390 /$ jmse 9090927 / s1, Figure S1: Images of the bedrock types used in the settlement experiments.

Author Contributions: All authors contributed to the research idea and experimental design. The experiments were performed by D.C.A. in the laboratory of and with assistance of R.L.V. The first draft and initial data analysis were completed by D.C.A. Subsequent drafts and data analysis were performed by W.G.A.J. and P.E.R. Funding for the research was acquired by R.L.V. R.L.V. read and agreed to publish an earlier version of this manuscript, but poor health prevented him from reading the current version. All authors have read and agreed to the published version of the manuscript.

Funding: The research was funded by the NOAA Sea Grant program of the University of Maine (\#NA89AADSG020 and \#NA16RGO157) and the USDA Hatch funds to Maine Agricultural and Forestry Experiment Station.

Institutional Review Board Statement: Not applicable.

Data Availability Statement: Data are available upon request from the first author.

Acknowledgments: We appreciate the use of the Bates College Geology Department rock saw, the use of the Fisheries and Aquaculture Research Group (FARG) facilities, and the assistance of FARG personnel with the seawater system. Comments by an anonymous reviewed significantly improved the manuscript.

Conflicts of Interest: The authors declare no conflict of interest.

\section{References}

1. Lewis, J.R. Water movements and their role in rocky shore ecology. Sarsia 1968, 34, 13-36. [CrossRef]

2. Crisp, D.J. Factors influencing the settlement of marine invertebrate larvae. In Chemoreception in Marine Organisms; Grant, P.T., Mackie, A., Eds.; Academic Press: London, UK, 1974; pp. 177-265.

3. Lobban, C.S.; Harrison, P.; Duncan, A.J. The Physiological Ecology of Seaweeds; Cambridge University Press: New York, NY, USA, 1985.

4. Mullineux, L.S.; Butnam, C.A. Initial contact, exploration, and attachment of barnacle (Balanus amphitrite) cyprids settling in flow. Mar. Biol. 1991, 110, 93-103. [CrossRef]

5. Smith, C.M. Diversity in intertidal habitats: An assessment of the marine algae of select islands in the Hawaiian Archipelago. Pac. Sci. 1992, 46, 466-479. 
6. Gaines, S.; Brown, S.; Roughgarden, J. Spatial variation in larval concentrations as a cause of spatial variation in settlement of the barnacle Balanus glandula. Oecologia 1985, 67, 267-272. [CrossRef]

7. Raimondi, P. Rock type affects settlement, recruitment, and zonation of the barnacle Chthamalus anispoma Pilsbury. J. Exp. Mar. Biol. Ecol. 1988, 123, 253-267. [CrossRef]

8. Menge, B.A. Relative importance of recruitment and other causes of variation in rocky intertidal community structure. J. Exp. Mar. Biol. Ecol. 1991, 146, 69-100. [CrossRef]

9. Valdivia, H.; Aguilera, M.A.; Navarrete, S.A.; Broitman, B.R. Disentangling the effects of propagule supply and environmental filtering on the spatial structure of a rocky shore metacommunity. Mar. Ecol. Prog. Ser. 2015, 538, 67-79. [CrossRef]

10. Pornerat, C.M.; Reiner, E.R. The influence of surface angle and light on the attachment of barnacles and other sedentary organisms. Biol. Bull. 1942, 82, 14-25.

11. Barnes, H.; Crisp, D.J.; Powell, H.T. Observations on the orientation of some species of barnacles. J. Anim. Ecol. 1951, 20, 227-241. [CrossRef]

12. Vaselli, S.; Bertocci, I.; Maggi, E.; Benedetti-Cecchi, L. Assessing the consequences of sea level rise: Effects of changes in the slope of the substratum on sessile assemblages of rocky shorelines. Mar. Ecol. Prog. Ser. 2008, 368, 9-22. [CrossRef]

13. Firth, L.B.; White, F.J.; Schofield, M.; Hanley, M.E.; Burrows, M.T.; Thompson, R.C.; Skov, M.W.; Evans, A.J.; Moore, P.J.; Hawkins, S.J. Facing the future: The importance of substratum features for ecological engineering of artificial habitats in the rocky intertidal. Mar. Fresh. Res. 2014, 67, 131-143. [CrossRef]

14. Paine, R.T. Disaster, catastrophe, and local persistence of the sea palm Postelsia palmaeformis. Science 1979, 17, 685-687. [CrossRef] [PubMed]

15. Ricketts, E.F.; Calvin, J.; Hedgpeth, J.W.; Phillips, D.W. Between Pacific Tides, 5th ed.; Stanford Univ. Press: Palo Alto, CA, USA, 1985.

16. Vadas, R.L.; Wright, W.A.; Miller, S.L. Recruitment of Ascophyllum nodosum: Wave action as a source of mortality. Mar. Ecol. Prog. Ser. 1990, 61, 263-272. [CrossRef]

17. Petraitis, P.S.; Methratta, E.T.; Rhile, E.C.; Vidargas, N.A.; Dudgeon, S.R. Experimental confirmation of multiple community states in a marine ecosystem. Oecologia 2009, 161, 139-148. [CrossRef] [PubMed]

18. Menge, B.A.; Menge, D.N.L. Dynamics of coastal meta-ecosystems: The intermittent upwelling hypothesis and a test in rocky intertidal regions. Ecol. Monogr. 2013, 83, 283-310. [CrossRef]

19. Ibanez-Erquiaga, B.; Pacheco, A.S.; Rivadeneira, M.M.; Tejada, C.L. Biogeographical zonation of rocky intertidal communities along the coast of Peru (3.5-13.5 S Southeast Pacific). PLoS ONE 2018, 13, e0208244. [CrossRef] [PubMed]

20. Fenberg, P.B.; Menge, B.A.; Raimondi, P.T.; Rivadeneira, M.M. Biogeographic structure of the northeastern Pacific rocky intertidal: The role of upwelling and dispersal drive patterns. Ecography 2015, 38, 83-95. [CrossRef]

21. Grabowska, M.; Grzelak, K.; Kuklińsk, P. Rock encrusting assemblages: Structure and distribution along the Baltic Sea. J. Sea Res. 2015, 103, 24-31. [CrossRef]

22. Malm, T.; Kautsky, L.; Claesson, T. The density and survival vesiculous L. (Fucales, Phaeophyta) on different bedrock types on a Baltic Sea moaraine coast. Botanica Mar. 2003, 46, 256-262. [CrossRef]

23. Guidetti, P.; Bianchi, C.N.; Chiantore, M.; Schiaparelli, S.; Morri, C.; Cattaneo-Vietti, R. Living on the rocks: Substrate mineralogy and the structure of subtidal rocky substrate communities in the Mediterranean Sea. Mar. Ecol. Prog. Ser. 2004, $274,57-68$. [CrossRef]

24. Sempere-Valverde, J.; Ostalé-Valriberas, E.; Farfán, G.M.; Espinosa, F. Substratum type affects recruitment and development of marine assemblages over artificial substrata: A case study in the Albaron Sea. Est. Coast. Shelf Sci. 2018, 204, 56-65. [CrossRef]

25. Liversage, K.; Janetzki, N.; Benkendorff, K. Association of benthic fauna with different rock types, and evidence of changing effects during succession. Mar. Ecol. Prog. Ser. 2014, 505, 131-143. [CrossRef]

26. Cerrano, C.; Arillo, A.; Bavestrello, G.; Benatti, U.; Calcinai, B.; Cattaneo-Vietti, R.; Cortesogno, L.; Gaggero, L.; Giovine, M.; Puce, S.; et al. Organism-quartz interactions in structuring benthic communities. Towards a marine bio-mineralogy? Ecol. Lett. 1999, 2, 1-3. [CrossRef]

27. Bavestrello, G.; Bianchi, C.N.; Calcinai, B.; Cattaneo-Vietti, R.; Cerrano, C.; Morri, C.; Puce, S.; Sara, M. Bio-mineralogy as a structuring factor for marine epibenthic communities. Mar. Ecol. Prog. Ser. 2000, 193, 241-249. [CrossRef]

28. Moore, H.B.; Kitching, J.A. The biology of Chthamalus stellatus (Poli). J. Mar. Biol. Assoc. UK 1939, 23, 521-541. [CrossRef]

29. Crisp, D.J.; Barnes, H. The orientation and distribution of barnacles and settlement with particular reference to surface contour. J. Anim. Ecol. 1954, 23, 142-162. [CrossRef]

30. Crisp, D.J.; Ryland, J.S. Influence of filming and surface texture on the settlement of marine organisms. Nature 1960, 185, 119. [CrossRef]

31. Harlin, M.M.; Lindbergh, J. Selection of substrata by seaweeds: Optimal surface relief. Mar. Biol. 1977, 40, 33-40. [CrossRef]

32. Wethey, D.S. Ranking of settlement cues by barnacle larvae: Influence of surface contour. Bull. Mar. Sci. 1986, 39, 393-400.

33. Barkai, A.; Branch, G.B. The influence of predation and substrate complexity on recruitment to settlement plates: A test of the theory of alternative states. J. Exp. Mar. Biol. Ecol. 1988, 124, 215-237. [CrossRef]

34. Chabot, R.; Bourget, E. Influence of substratum heterogeneity and settled barnacle density on the settlement of Cypris larvae. Mar. Biol. 1988, 97, 45-56. [CrossRef] 
35. Le Tourneux, F.; Bourget, E. Importance of physical and biological settlement cues used at different spatial scales by the larvae of Semibalanus balanoides. Mar. Biol. 1988, 97, 57-66. [CrossRef]

36. Wells, J.; Moll, E.J.; Bolton, J.J. Substrate as a determinant of marine intertidal algal communities at Smitswinkle Bay, False Cay, Cape. Mar. Bot. 1989, 32, 499-502. [CrossRef]

37. Anderson, M.J.; Underwood, A.J. Effects of substratum on the recruitment and development of an intertidal estuarine fouling assemblage. J. Exp. Mar. Biol. Ecol. 1994, 184, 217-236. [CrossRef]

38. Gersun, L.; Anderson, R.J.; Hart, J.R.; Maneveldt, G.W.; Bolton, J.J. Sublittoral seaweed communities on natural and artificial substrata in a high-latitude coral community in South Africa. Afr. J. Mar. Sci. 2016, 38, 303-316. [CrossRef]

39. Chase, A.L.; Dijkstra, J.A.; Harris, L.G. The influence of substrate material on ascidian larval settlement. Mar. Poll. Bull. 2016, 106, 35-42. [CrossRef] [PubMed]

40. Brzozowska, A.M.; Maassen, S.; Rong, R.G.Z.; Benke, P.I.; Lim, C.-S.; Marzinelli, E.M.; Janczewski, D.; Teo, S.L.-M.; Vancso, G.J. Effect of variations in micropatterns and surface modulus on marine fouling of engineering polymers. Appl. Mater. Interfaces 2017, 9, 17508-17516. [CrossRef]

41. Kerrison, P.; Stanley, M.; Mitchell, E.; Cunningham, L.; Hughes, A. A life-stage conflict of interest in kelp: Higher meiospore settlement where sporophyte attachment is weak. Algal Res. 2018, 35, 309-318. [CrossRef]

42. Erramilli, S.; Genzer, J. Influences of surface topography attributes on settlement and adhesion of natural and synthetic species. Soft Matter 2019, 15, 4045-4067. [CrossRef]

43. Hardy, F.G.; Moss, B.L. The effects of the substratum on the morphology of the rhizoids of Fucus germlings: Est. Coast. Mar. Sci. 1979, 9, 577-584. [CrossRef]

44. Fletcher, R.L.; Callow, M. The settlement, attachment, and establishment of marine algal spores. Brit. Phycol. J. 1992, 27, 303-329. [CrossRef]

45. Callow, M.E.; Fletcher, R.L. The influence of low surface energy materials on bioadhesion-A review. J. Int. Biodeterior. Biodegrad. 1994, 34, 333-348. [CrossRef]

46. Pradhan, S.; Kumar, S.; Mohanty, S.; Nayak, S.K. Environmentally Benign Fouling-Resistant Marine Coatings: A Review. Polym.-Plast. Technol. Eng. 2019, 58, 498-518. [CrossRef]

47. Leonardi, A.K.; Ober, C.K. Polymer-based marine antifouling and fouling release surfaces: Strategies for synthesis and modification. Ann. Rev. Chem. Biomol. Engin. 2019, 10, 241-264. [CrossRef]

48. Chapman, A.R.O. Functional ecology of fucoid algae: Twenty-three years of progress. Phycologia 1995, 34, 1-32. [CrossRef]

49. Norton, T.A.; Fetter, R. The settlement of Sargassum muticum propagules in stationary and flowing water. J. Mar. Biol. Assoc. UK 1981, 61, 929-940. [CrossRef]

50. Le, H.N.; Hughes, A.D.; Kerrison, P.D. Early development and substrate twice selection for the cultivation of Sargassum muticum (Yendo) Fensholt under laboratory conditions. J. Appl. Phycol. 2018, 30, 2475-2483. [CrossRef]

51. Taylor, D.I.; Schiel, D.R. Wave-related mortality in zygotes of habit-forming algae from different exposures in southern New Zealand: The importance of 'stickability'. J. Exper. Mar. Biol. Ecol. 2003, 290, 229-245. [CrossRef]

52. Dimartino, S.; Mather, A.V.; Nowell-Usticke, J.S.; Fischer, B.; Nock, V. Investigation of the adhesive from Hormosira banksia germlings and its performance over different material surfaces and topographies. Inter. J. Adhes. Adhes. 2017, 75, 114-123. [CrossRef]

53. Hussey, A.M., II; Berry, H.N., IV. Bedrock Geology of the Bath 1:100,000 Map Sheet, Coastal Maine; Map 02-152; Maine Geological Survey: Augusta, ME, USA, 2002.

54. Vreeland, V.; Grotkopp, S.; Espinosa, S.; Quiroz, D.; Laetsch, W.M.; West, J. The pattern of cell wall adhesive formation by Fucus zygotes. Hydrobiologia 1993, 260/261, 485-491. [CrossRef]

55. Niemeck, R.A.; Mathieson, A.C. An ecological study of Fucus spiralis (L.). J. Exp. Mar. Biol. Ecol. 1976, 24, 33-48. [CrossRef]

56. Thelin, I. Effects, en culture, de deux petroles bruts et d'un petrolier sur les zygotes et les plantules, de Fucus serratus Linnaeus (Fucales, Phaeophyceae). Bot. Mar. 1981, 24, 515-519. [CrossRef]

57. Vadas, R.L.; Johnson, S.; Norton, T.A. Recruitment and mortality of early post-settlement stages of benthic algae. Brit. Phycol. J. 1992, 27, 331-351. [CrossRef]

58. Rohlf, F.J.; Sokal, R.R. Statistical Tables; W. H. Freeman and Company: San Francisco, CA, USA, 1969.

59. Zar, J.H. Biostatistical Analysis, 2nd ed.; Prentice Hall: Englewood Cliffs, NJ, USA, 1984.

60. Potin, P.; Leblanc, C. Phenolic-based adhesives of marine brown algae. In Biological Adhesives; Smith, A.M., Callow, J.A., Eds.; Springer: Berlin/Heidelberg, Germany, 2006; pp. 105-124.

61. Britton, R.; Ben-Yehuda, M.; Davidovich, M.; Balazs, Y.; Potin, P.; Delage, L.; Colin, C.; Bianco-Peled, H. Structure of algal-born phenolic polymeric adhesives. Macromol. Biosci. 2006, 6, 737-746. [CrossRef] [PubMed]

62. Bourget, E.; DeGuise, J.; Daigle, G. Scale of substratum heterogeneity structural complexity, and the early establishment of a marine epibenthic community. J. Exp. Mar. Biol. Ecol. 1994, 181, 31-51. [CrossRef]

63. Schumacher, J.F.; Carman, M.L.; Estes, T.G.; Feinberg, A.W.; Wilson, L.H.; Callow, M.E.; Callow, J.A.; Finlay, J.A.; Brennan, A.G. Engineered Antifouling Microtopographies-Effect of Feature Size, Geometry, and Roughness on Settlement of Zoospores of the Green Alga Ulva. Biofouling 2007, 23, 55-62. [CrossRef] [PubMed]

64. Holmes, S.P.; Sturgess, C.J.; Davies, M.S. The effect of rock-type on the settlement of Balanus balanoides (L.) cyprids. Biofouling 1997, 11, 137-147. [CrossRef] 
65. McGuinness, K.A.; Underwood, A.J. Habitat structure of communities on intertidal boulders. J. Exp. Mar. Biol. Ecol. 1986, 104, 97-123. [CrossRef]

66. Barnes, H. Surface roughness and the settlement of Balanus balanoides. Arch. Soc. Zool.-Bot. Fenn. Vanamo 1956, 10, 164-168.

67. Caffey, H.M. No effect of naturally occurring rock types on settlement or survival of the intertidal barnacle Tessoropora rosea. J. Exp. Mar. Biol. Ecol. 1982, 63, 119-132. [CrossRef]

68. Caffey, H.M. Spatial and temporal variation in settlement and recruitment of intertidal barnacles. Ecol. Monogr. 1994, 55, 313-332. [CrossRef]

69. Scardino, A.J.; Guenther, J.; de Nys, R. Attachment point theory revisited: The fouling response to a microtextured matrix. Biofouling 2008, 24, 45-53. [CrossRef] [PubMed]

70. Roberts, D.; Rittschof, D.; Holm, E.; Schmidt, A.R. Factors influencing initial larval settlement temporal, spatial and surface molecular components. J. Exp. Mar. Biol. Ecol. 1991, 150, 203-211. [CrossRef]

71. Jaycock, M.J.; Parfitt, G.D. Chemistry of Interfaces; John Wiley and Sons: New York, NY, USA, 1981.

72. Adamson, A.W. Physical Chemistry of Surfaces; John Wiley and Sons: New York, NY, USA, 1982.

73. Holm, E.R.; Cannon, G.; Roberts, D.; Schmidt, A.R.; Sutherland, J.P.; Rittschof, D. The influence of initial surface chemistry on development of the fouling community at Beaufort North Carolina. J. Exp. Mar. Biol. Ecol. 1997, 215, 189-203. [CrossRef]

74. Grzegorczyk, M.; Pogorzelski, S.J.; Pospiech, A.; Boniewicz-Szmyt, B. Monitoring of marine biofilm formation dynamics at submerged solid surfaced with miltitechnique sensors. Front. Mar. Sci. 2018, 10, 363. [CrossRef]

75. Mieszkin, S.; Callow, M.E.; Callow, J.A. Interactions between microbial biofilms and marine fouling algae: A mini review. Biofouling 2013, 29, 1097-1113. [CrossRef]

76. Hou, Y.; Xiaoping, J.; Li, J.; Xianghang, L. Adhesion between asphalt and recycled concrete aggregate and its impact on properties of asphalt mixture. Materials 2018, 11, 2528. [CrossRef]

77. Wright, J.; Reed, R.H. Effects of osmotic stress on gamete size, rhizoid initiation and germling growth in fucoid algae. Brit. Phycol. J. 1990, 25, 149-155. [CrossRef]

78. Maki, J.S.; Rittschof, D.; Schmidt, A.R.; Snyder, A.G.; Mitchell, R. Factors controlling attachment of bryozoan larvae: A comparison of bacterial films and unfilmed surfaces. Biol. Bull. 1989, 177, 295-302. [CrossRef]

79. Becker, K. Attachment strength and colonization patterns of two macrofouling species on substrata with different surface tension (in situ studies). Mar. Biol. 1993, 117, 301-309. [CrossRef]

80. Allen, T.F.H. Scale in microscopic algal ecology: A neglected dimension. Phycologia 1977, 16, 253-257. [CrossRef]

81. Amsler, C.D.; Reed, D.C.; Neushul, M. The microclimate inhabited by macroalgal propagules. Brit. Phycol. J. 1992, 27, 253-270. [CrossRef]

82. Maki, J.S.; Rittschof, D.; Mitchell, R. Inhibition of larval barnacle attachment to bacterial films: An investigation of physical properties. Microb. Ecol. 1992, 23, 97-106. [CrossRef] [PubMed]

83. Pershing, A.J.; Alexander, M.A.; Brady, D.C.; Brickman, D.; Curchitser, E.N.; Diamond, A.W.; McClenachan, L.M.; Mills, K.E.; Nichols, O.C.; Pendleton, D.E.; et al. Climate impacts of the Gulf of Maine ecosystem: A review of observed and expected changes in 2050 from rising temperatures. Elem. Sci. Anth. 2021, 9, 76. [CrossRef] 